\title{
HASIL BELAJAR AKUNTANSI BANK MELALUI MODEL COOPERATIVE LEARNING SISWA KELAS XII AKUNTANSI 2 SMK NEGERI 1 RENGAT
}

\author{
Arminiyetti ${ }^{1}$ \\ ${ }^{1}$ SMK Negeri 1 Rengat \\ e-mail: 1arminiyetti1@gmail.com
}

\begin{abstract}
Abstrak
Tujuan dari penelitian ini adalah untuk meningkatkan hasil belajar akuntansi bank siswa melalui model pembelajaran kooperatif. Jenis penelitian yang digunakan adalah penelitian tindakan kelas yang dilaksanakan dalam 3 siklus. Subjek dalam penelitian ini adalah peserta didik kelas XI akuntasi SMK Negeri 1 Rengat. Data dalam penlitian ini didapatkan dari penilaian proses kegiatan belajar mengajar, hasil belajar siswa berupa nilai test formatif dan aktivitas siswa yang didapatkan dari hasil observasi. Dari hasil penelitian didapatkan data bahwa model cooperative learning dapat meningkatkan hasil belajar mengelola akuntansi bank siswa.
\end{abstract}

Kata kunci: Prestasi Belajar, Bertukar Pasangan, Akuntansi, Hasil belajar

\begin{abstract}
The purpose of this study is to improve student accounting learning outcomes through cooperative learning models. This type of research is a classroom action research conducted in 3 cycles. The subjects in this study were students of class XI accounting at SMK Negeri 1 Rengat. The data in this study were obtained from the assessment of the teaching and learning process, student learning outcomes form the formative test scores and student activities obtained from observations. From the results of the study obtained data cooperative learning models can improve bank student accounting learning outcomes
\end{abstract}

Keywords: Learning Achievemnet, Couple Eexchange, Learning Outcome.

\section{Pendahuluan}

Dalam situasi masyarakat yang selalu berubah, idealnya pendidikan tidak hanya berorientasi pada masa lalu dan masa kini, tetapi sudah seharusnya merupakan proses yang mengantisipasi dan membicarakan masa depan. Pendidikan hendaknya melihat jauh ke depan dan memikirkan apa yang akan dihadapi peserta didik dimasa yang akan datang. Pendidikan yang baik adalah pendidikan yang tidak hanya mempersiapkan para siswanya untuk sesuatu profesi atau jabatan, tetapi untuk menyelesaikan masalah-masalah yang dihadapinya dalam kehidupan sehari-hari.

Salah satu pokok pembelajaran pada pendidikan formal (sekolah) dewasa ini adalah masih rendahnya daya serap peserta didik. Hal ini Nampak rata hasil belajar peserta didik yang senantiasa masih sangat memprihatinkan. Prestasi ini tentunya merupakan hasil kondisi pembelajaran yang masih bersifat konvensional dan tidak menyentuh dimensi perserta didik itu sendiri, yaitu bagaimana sebenarnya belajar itu (belajar untuk belajar). Dalam arti substansial, bahwa proses pembelajaran hingga dewasa ini masih memberikan dominasi guru dan tidak memberikan akses bagi siswa untuk berkembang secara mandiri melalui penemuan dan proses berpikirnya.

Pendidikan hendaknya melihat dan memikirkan apa yang akan dihadapi peserta didik dimasa yang akan datang. Pendidikan yang baik adalah pendidikan yang tidak hanya 
mempersiapkan siswanya untuk sesuatu profesi atau jabatan, tetapi juga untuk menyelesaikan masalah-masalah dalam kehidupan sehari-hari [1]. Kurangnya media pembelajaran membuat siswa kurang tertarik untuk mengikuti proses belajar mengajar hal ini menyebabkan pengajaran menjadi monoton dan siswa menjadi mudah jenuh [2]. Fasilitas sekolah termasuk alat peraga yang kurang memadai semakin menambah lengkapnya penyebab kurang tercapainya proses pembelajaran dengan baik. Model pembelajaran klasik yang selama ini digunakan guru rupanya tidak membantu siswa dalam memahami konsep pelajaran. Pembelajaran kelas yang cenderung teacher-centere mengakibatkan peserta didik menjadi pasif. Meskipun demikian sampai saat ini guru lebih suka menerapkan model tersebut, sebab tidak memerlukan alat dan bahan praktik, cukup menjelaskan konsep-konsep yang ada pada buku ajar atau referensi lain. Dalam hal ini siswa tidak diajarkan strategi belajar yang dapat memahami bagaimana belajar, berpikir, dan memotivasi diri sendiri.

Menurut Gagne [3] belajar merupakan kegiatan yang kompleks setelah belajar orang memiliki keterampilan, pengetahuan, sikap dan nilai. Timbulnya kapabilitas yaitu dari stimulus yang berasal dari lingkungan dan proses kognitif siswa. Dengan demikian, belajar adalah seperangkat proses kognitif yang mengubah sifat stimulasi lingkungan, melewati pengolahan informasi, menjadi kapabilitas baru. Menurut Winkel [4] belajar adalah suatu proses psikis yang berlangsung dalam interaksi aktif subjek dengan lingkungannya dan menghasilkan perubahanperubahan dalam pengetahuan, pemahaman keterampilan, nilai sikap yang bersifat konstan/menetap. Perubahan-perubahan itu dapat berupa suatu yang baru, yang segera tampak dalam perilaku nyata atau masih tinggal tersembunyi, perubahan juga bisa berupa penyempurnaan terhadap hal-hal yang sudah pernah dipelajari.

Model pembelajaran klasik yang selama ini digunakan guru rupanya tidak membantu siswa dalam memahami konsep pelajaran. Pembelajaran yang cenderung teacher-centred mengakibatkan peserta didik menjadi pasif [5]. Meskipun demikian sampai saat ini guru lebih suka menerapkan model tersebut, sebab tidak memerlukan alat dan bahan praktik, cukup menjelaskan konsep-konsep yang ada pada buku ajar atau referensi lain. Model pembelajaran yang bersifat partisipatoris yang dilakukan guru akan mampu membawa siswa dalam situasi yang lebih kondusif, karena siswa lebih berperan dan lebih terbuka serta sensitif dalam kegiatan belajar mengajar [6].

Siswa di SMK N 1 Rengat sebagian besar berada di daerah yang jauh dari fasilitas belajar yang memadai sehingga daya pikirnya berbeda dengan siswa-siswi yang berada di kota-kota yang memiliki fasilitas belajar yang lebih lengkap. Berdasarkan keadaan di lapangan, kebutuhan inovasi pembelajaran dari guru menjadi sangat penting untuk meningkatkan hasil belajar dan aktivitas belajar siswa, terutama dalam mengelola akuntansi bank yang memerlukan keaktifan siswa dalam belajar. Interaksi siswa dan guru, siswa dan siswa harus ditingkatkan.

Dengan memperhatikan hal-hal tersebut,maka perlu diterapkan suatu model pembelajaran yang dapat memudahkan siswa dalam menyerap pengetahuan yang diberikan oleh gurunya, dalam hal ini model pembelajaran kooperatif diharapkan dapat meningkatkan daya serap siswa terhadap mata pelajaran mengelola akuntansi bank, yang mana mata pelajaran akuntansi bank yang bersifat teori dan praktek sehingga akan lebih mudah dipahami jika dipelajari secara bersama-sama atau berkelompok. Menurut paradigma konstruktivistik, pembelajaran lebih diutamakan untuk membantu siswa dalam menginternalisasi, membentuk kembali, atau mentransformasi informasi baru [7]. Untuk menginternalisasi serta dapat menerapkan model pembelajaran menurut paradigma konstruktivistik, terlebih dulu guru diharapkan dapat mengubah pikiran sesuai dengan pandangan konstruktivistik. Model pembelajaran terdiri dari model pembelajaran langsung, model pembelajaran kooperatif, model pembelajaran berdasarkan masalah, model pembelajaran diskusi, dan model pembelajaran strategi.

Penerapan Model pembelajaran merupakan salah satu komponen yang penting dalam kegiatan belajar mengajar di kelas, karena dengan model pembelajaran itu guru dapat menciptakan kondisi belajar yang mendukung pencapaian tujuan pembelajaran. Selain itu, penggunaan model pembelajaran yang dipilih dan dipergunakan dengan baik oleh guru dapat 
mendorong siswa untuk aktif mengikuti kegiatan belajar di dalam kelas. Pemilihan model pembelajaran harus dilandaskan pada pertimbangan menempatkan siswa sebagai subjek belajar yang tidak hanya menerima secara pasif apa yang disampaikan oleh guru. Guru harus menempatkan siswanya sebagai insan yang secara alami memiliki pengalaman, pengetahuan, keinginan, dan pikiran yang dapat dimanfaatkan untuk belajar, baik secara individual maupun berkelompok.

Model pembelajaran kooperatif adalah model pembelajaran yang menempatkan guru fasilitator untuk menciptakan situasi interaktif yang edukatif, yakni interaktif antara guru dengan siswa, serta siswa dengan siswa. Pembelajaran kooperatif atau Cooperative learning mencakup suatu kelompok kecil siswa yang bekerja sebagai sebuah tim untuk menyelesaikan sebuah masalah, menyelesaikan suatu tugas, atau mengerjakan sesuatu untuk mencapai tujuan bersama [8]. Setiap manusia memiliki derajat potensi, latar belakang historis, serta harapan masa depan yang berbeda-beda. Karena perbedaan itulah manusia dapat saling asah, asih, dan asuh (saling mencerdaskan). Pembelajaran kooperatif dapat menciptakan interaksi yang saling asah, asih, dan asuh sehingga terciptalah masyarakat belajar (learning community) [9]. Model pembelajaran cooperative learning tidak sama dengan sekadar belajar dalam kelompok. Ada unsur-unsur dasar pembelajaran cooperative learning yang membedakannya dengan pembagian kelompok yang dilakukan asal-asalan. Pelaksanaan prosedur Model Pembelajaran Cooperative Learning dengan benar akan memungkinkan pendidik mengelolah kelas lebih efektif.

Berdasarkan uraian tersebut diatas bahwa pembelajaran akuntansi bank tidak efektif jika hanya menggunkan model pembelajaran yang konvensional karena pada pembelajaran ini perlu adanya teman untuk saling memberikan masukan satu sama lainnya dengan kata lain untuk saling bertukar pikiran dalam menyelesaikan latihan soal. Maka diharapkan melalui model pembelajaran kooperatif dapat meningkatkan pemahaman siswa terhadap mata pelajaran akuntansi bank. Sehubungan dengan permasalahan di atas, maka rumusan masalah yang dikemukakan diatas dalam penelitian ini adalah: " apakah dengan menggunakan Model Pembelajaran Cooperative Learning dapat meningkatkan hasil belajar dan aktifitas belajar akuntansi bank pada siswa kelas XII akuntansi SMK Negeri 1 Rengat tahun 2017.

Tujuan yang akan dicapai dalam penelitian ini adalah untuk mengetahui kemampuan guru dalam mengalola pembelajaran akuntansi bank dengan menggunakan keterlibatan siswa secara aktif pada pembelajaran akutansi bank. Untuk mengetahui hasil prestasi siswa swcara aktif pada pembelajaran Cooperative Learning diberikan kepada siswa. Mendekripsikan persepsi siswa terhadap Model Pembelajaran Cooperative Learning selama proses pembelajaran akuntansi bank dilaksanakan di kelas.

Manfaat yang diharapkan setelah penelitian ini bagi siswa, mempunyai sikap ilmiah yang tinggi, mempunyai kecakapan hidup dan tanggap terhadap lingkungan, sebagai alternative untuk emecahkan masalah yang dihadapi dalam upaya meningkatkan siswa untuk saling belajar. Bagi guru, model yang diterapkan yaitu Model Pembelajaran Cooperative Learning menjadikan bahan ajar yang lebih menarik, sehingga proses pembelajaran berjalan sesuai dengan tujuan dan prestasi akademik siswa smakin meningkat.

\section{Metode Penelitian}

\subsection{Waktu dan Tempat}

Penelitian tindakan ini dilaksanakan tahun 2015 secara terjadwal selama dua bulan dimulai dari bulan September s/d bulan Oktober 2017. Penelitian ini dilaksanakan dengan dua siklus. Di mana kedua siklus tersebut merupakan rangkaian kegiatan yang saling berkaitan. Artinya pelaksanaan siklus II merupakan kelanjutan dan perbaikan dari siklus I [10]. 
Plan

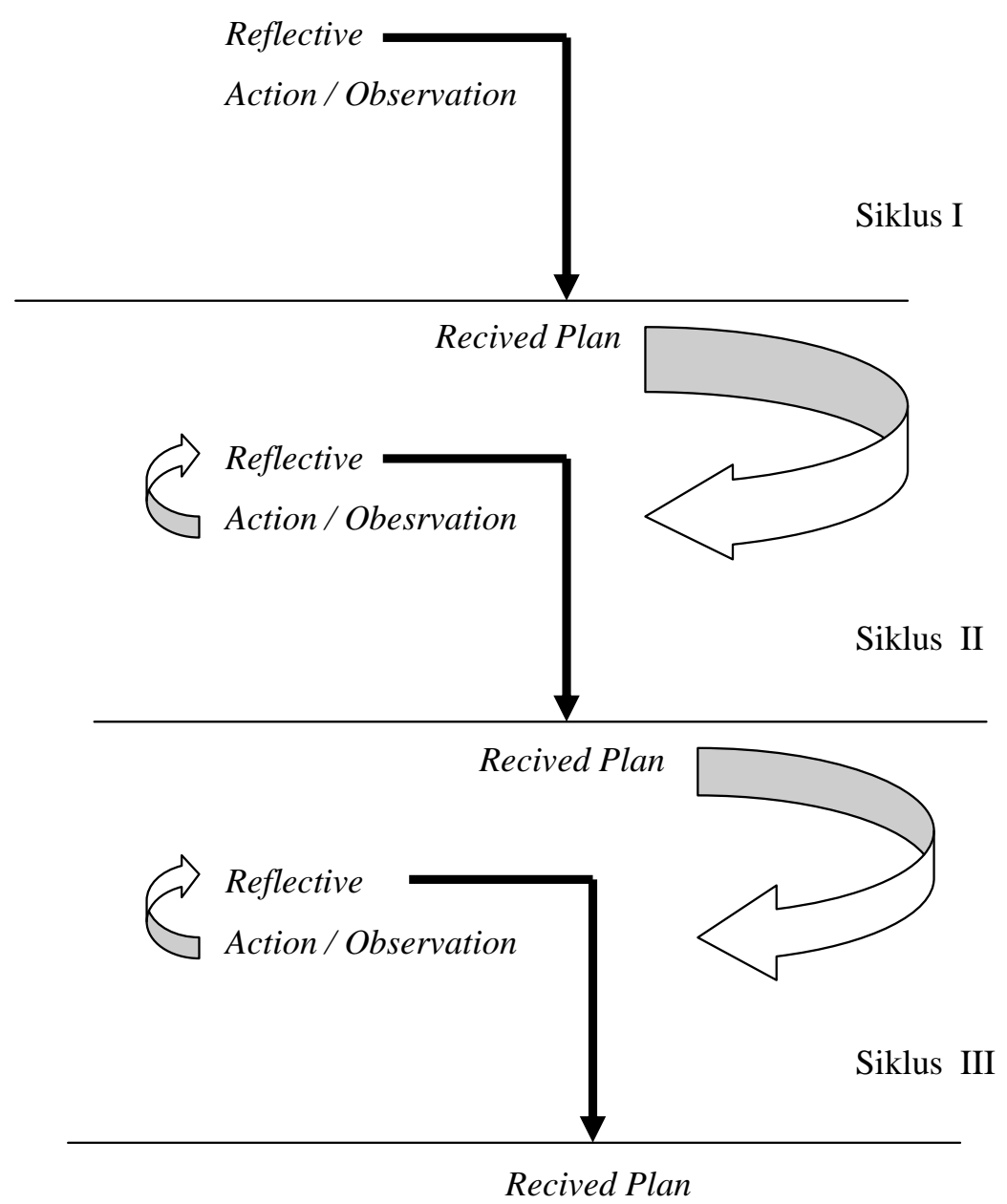

Gambar 1. Siklus Penelitian Tindakan Kelas

\subsection{Subjek Penelitian}

Subyek penelitian ini adalah siswa SMK Negeri 1 Rengat. kelas XI Akuntansi 2. Jumlah sebanyak 34 siswa dengan komposisi terdiri dari 15 siswa laki-laki dan 19 siswa perempuan. peneliti mengambil kelas ini sebagai subjek penelitian karena kelas ini cukup mewakili dari jumlah siswa XI akuntansi SMK Negeri 1 Rengat.

\subsection{Sumber dan Teknik Pengumpulan Data}

Data dari penelitian tindakan ini bersumber dari hasil tes dan observasi. Tes dilakukan untuk mengetahui hasil belajar siswa, sedangkan observasi dilakukan untuk mengetahui aktifitas siswa dan kinerja guru. 
Tabel 1. Tabel Observasi Aktivitas Belajar Peserta DIdik

\begin{tabular}{|c|c|c|c|c|c|c|c|c|c|c|c|c|c|c|c|c|c|}
\hline \multirow[b]{3}{*}{ No } & \multirow{3}{*}{ Nama Siswa } & \multicolumn{15}{|c|}{ Aktivitas Belajar Siswa } & \multirow{3}{*}{$\begin{array}{l}\text { Nilai rata- } \\
\text { Rata } \\
\text { Pertemuan } \\
1,2 \text { dan } 3\end{array}$} \\
\hline & & \multicolumn{5}{|c|}{ Pert 1} & \multicolumn{5}{|c|}{ Pert 2} & \multicolumn{5}{|c|}{ Pert 3} & \\
\hline & & 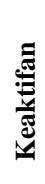 & 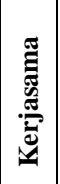 & 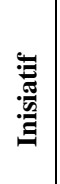 & 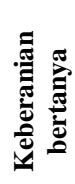 & 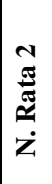 & 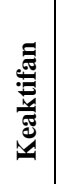 & 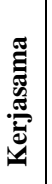 & 嘕 & 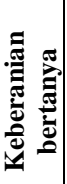 & 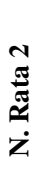 & 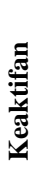 & 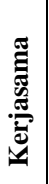 & 槖 & 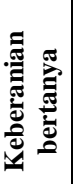 & 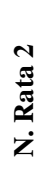 & \\
\hline \multicolumn{18}{|l|}{1} \\
\hline \multicolumn{18}{|l|}{2} \\
\hline \multicolumn{18}{|l|}{3} \\
\hline \multicolumn{18}{|l|}{ Dst } \\
\hline \multicolumn{18}{|c|}{ Jumlah siswa aktif } \\
\hline \multicolumn{2}{|c|}{ Jumlah siswa tidak aktif } & & & & & & & & & & & & & & & & \\
\hline
\end{tabular}

\subsection{Teknik Analisis Data}

Teknik analisis data dalam Penelitian Tindakan kelas ini menggunakan analisis kualitatif dan kuantatif.

a. Analisis kualititaif. Digunakan untuk menganalisis data, angket digunakan untuk menjaring aktifitas belajar siswa, model jigsaw dalam pembelajaran akuntansi bank.

1) Rumus analisis aktifitas belajar siswa

Persentase aktivitas belajar siswa $=\frac{\text { Jumlah seluruh siswa }}{\text { Jumlah siswa yang aktif }} \times 100 \%$

2) Rumus analisis hasil kerja kelompok

$$
\text { Skor akhir }=\frac{\text { Jumlah skor maksimal }}{\text { Jumlah skor yang didapat }} \times 100
$$

b. Analisis kuantitatif. Digunakan untuk mendeskripsikan hasil belajar siswa dalam hubungannya dalam penguasaan materi yang diajarkan guru.

$$
\text { Nilai Akhir = } \frac{\text { Skor yang diperoleh }}{\text { Skor Maksimal }}
$$

Selanjutnya nilai rata-rata hasil belajar siswa dihitung dengan menggunakan rumus ratarata hitung:

$$
\bar{x}=\frac{\sum x i}{n}
$$

\section{Keterangan :}




$$
\begin{array}{ll}
\bar{x} & =\text { Nilai rata-rata yang dicari } \\
\sum x i & =\text { jumlah nilai } \\
n & =\text { Jumlah aspek yang dinilai }
\end{array}
$$

\section{Hasil dan Pembahasan}

\subsection{Deskripsi Lingkungan Sekolah}

Penelitian ini dilaksanakan di SMK Negeri 1 Rengat. SMK Negeri 1 Rengat pada tahun 2017 beralamat di jalan Sultan Km 4. Kelurahan Nara Singa Kecamatan Rengat, Kabupaten Indragiri Hulu, Propinsi Riau. Dipimpin oleh bapak Drs.Adimirwan Nip. 19650801 1995121001. Staf pengajar dan karyawan baik PNS maupun honor berjumlah 88 orang. SMK Negeri 1 Rengat berdiri dari tahun 1960-an, pada awal pendirian merupakan sekolah yayasan SMK Indragiri. Kemudian sesuai dengan perkembangan sekolah dan jumlah siswa SMK Indaragiri dinegerikan pada tahun 1978-1979 dibawah kepemimpinan bapak Drs. Zumani Mampai dan program diklat terdiri dari: Tata Buku, Tata Niaga dan Tata Usaha. Perkembangannya yang sangat pesat karena ditunjang dengan tingkat ekonomi dan keinginan masyarakat untuk meningkatkan kwalitas generasi menjadi kwalitas yang lebih baik. jumlah rombel di SMK Negeri 1 Rengat terdiri dari beberapa program studi sebagai berikut

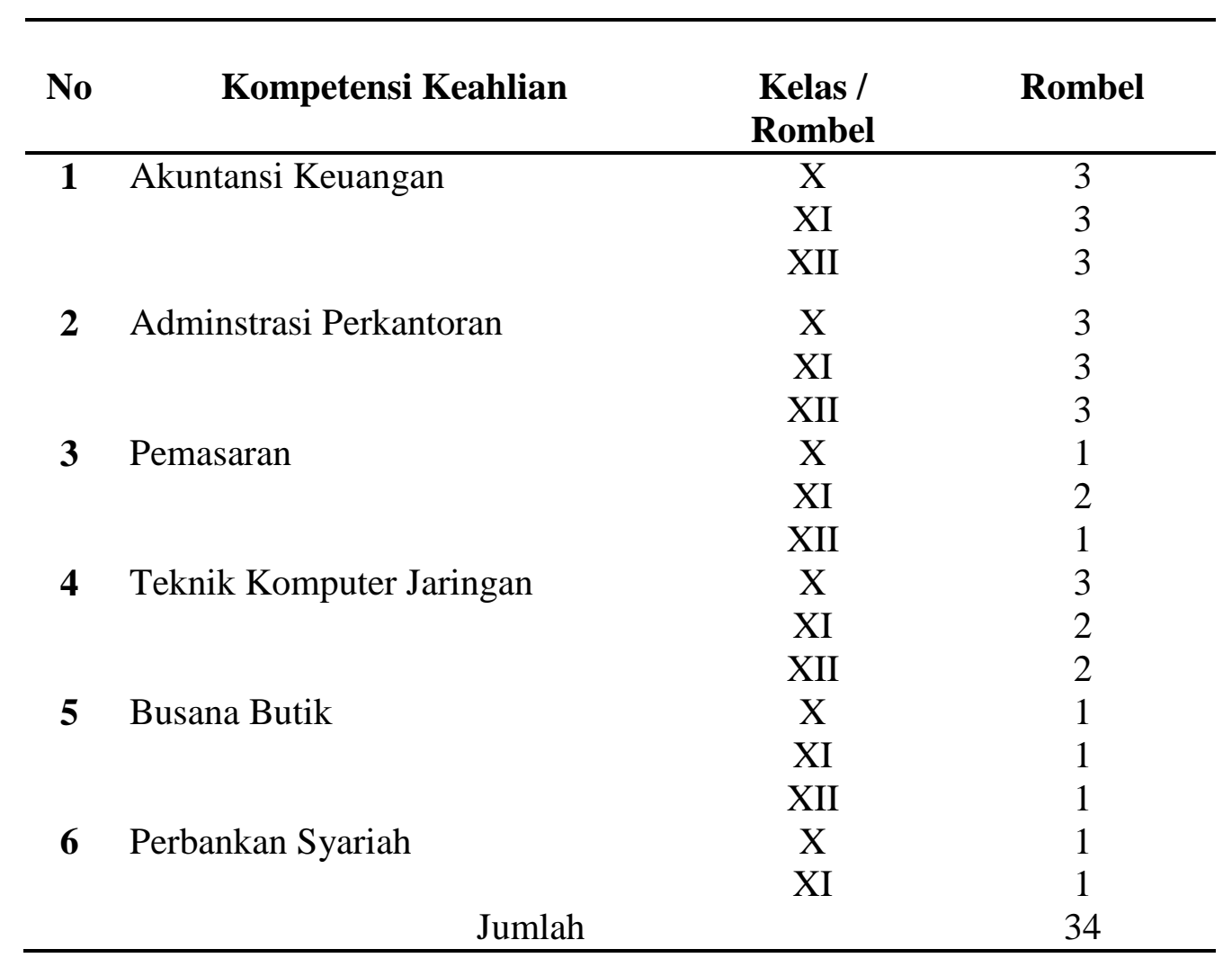

\subsection{Hasil Pelaksanaan Tindakan}

\subsubsection{Siklus 1}

Pada siklus 1, petemuan pertama pembelajaran hari ini mengerjakan praktek spreadsheet di komputer belum dapat dikerjakan dengan teratur mengerjakannya dengan model betukar pasangan dalam tiga kelompok, satu kelompok terdiri dari 2 orang dalam arti satu komputer ditempati oleh dua orang. Jadi mereka bertukar pasangangan untuk tiga komputer mengerjakan satu siklus akuntansi secara bergantian dengan tanggung jawab masing-masing tugas belum dapat mengerjakan tugasnya dengan sempurna. Untuk itu pada pertemuan kedua 
siklus 1( pertama) akan diperbaiki lagi agar lebih efektif belajar dengan model pembelajaran yang dilakukan. Berdasarkan hasil pengumpulan data pada Siklus I, pertemuan pertama dan pertemuan kedua maka diperoleh rekapitulasi sebagai berikut.

Tabel 2. Rekapitulasi Data Pengamatan Proses Belajar pada Siklus 1 Pertemuan Pertama

\begin{tabular}{|c|c|c|c|c|c|}
\hline \multirow[t]{2}{*}{ NO } & \multirow[t]{2}{*}{ AKTIVITAS } & \multirow[t]{2}{*}{$\sum$ siswa } & \multicolumn{3}{|c|}{ SCORE } \\
\hline & & & $\mathrm{A}$ & B & $\mathrm{C}$ \\
\hline 1 & Kesiapan belajar & 34 & 0 & 14 & 20 \\
\hline 2 & Interaksi antarsiswa & 34 & 1 & 13 & 20 \\
\hline 3 & Interaksi siswa guru & 34 & 0 & 0 & 34 \\
\hline 4 & Mengumpulkan tugas tepat waktu & 34 & 0 & 2 & 32 \\
\hline 5 & Mengerjakan tugas sesuai petunjuk & 34 & 0 & 7 & 27 \\
\hline 6 & Tidak menyontek & 34 & 0 & 31 & 3 \\
\hline \multirow{2}{*}{\multicolumn{2}{|c|}{ Presentasi }} & 204 & 1 & 67 & 136 \\
\hline & & $100 \%$ & $0,49 \%$ & $32,84 \%$ & $66,67 \%$ \\
\hline
\end{tabular}

Tabel 3. Rekapitulasi Data Pengamatan Proses Belajar pada Siklus 1 Pertemuan Kedua

\begin{tabular}{rlcccc}
\hline NO & \multicolumn{1}{c}{ AKTIVITAS } & $\sum$ siswa & \multicolumn{3}{c}{ SCORE } \\
\cline { 4 - 6 } $\mathbf{1}$ & Kesiapan belajar & & $\mathrm{A}$ & $\mathrm{B}$ & $\mathrm{C}$ \\
$\mathbf{2}$ & Interaksi antarsiswa & 34 & 0 & 13 & 21 \\
$\mathbf{3}$ & Interaksi siswa guru & 34 & 1 & 13 & 20 \\
$\mathbf{4}$ & Mengumpulkan tugas tepat waktu & 34 & 0 & 2 & 32 \\
$\mathbf{5}$ & Mengerjakan tugas sesuai petunjuk & 34 & 0 & 5 & 29 \\
$\mathbf{6}$ & Tidak menyontek & 34 & 2 & 16 & 18 \\
& Jumlah & 204 & 3 & 79 & 122 \\
\multirow{2}{*}{ Presentasi } & $100 \%$ & $1,47 \%$ & $38,73 \%$ & $59,80 \%$ \\
\hline
\end{tabular}

Untuk hasil belaar peserta didik pada siklus I dalam penerapan model pembalajran bertukar pasangan dilaksanakan pada setiap akhir pertemuan. Untuk pengukuran hasil beljar menggunakan instrumen hasil belajar berupa soal formatif dengan jumlah 20 butir. Adapun deskripsi hasil beajar pada iklus I dapat dilihat pada grafik berikut. 


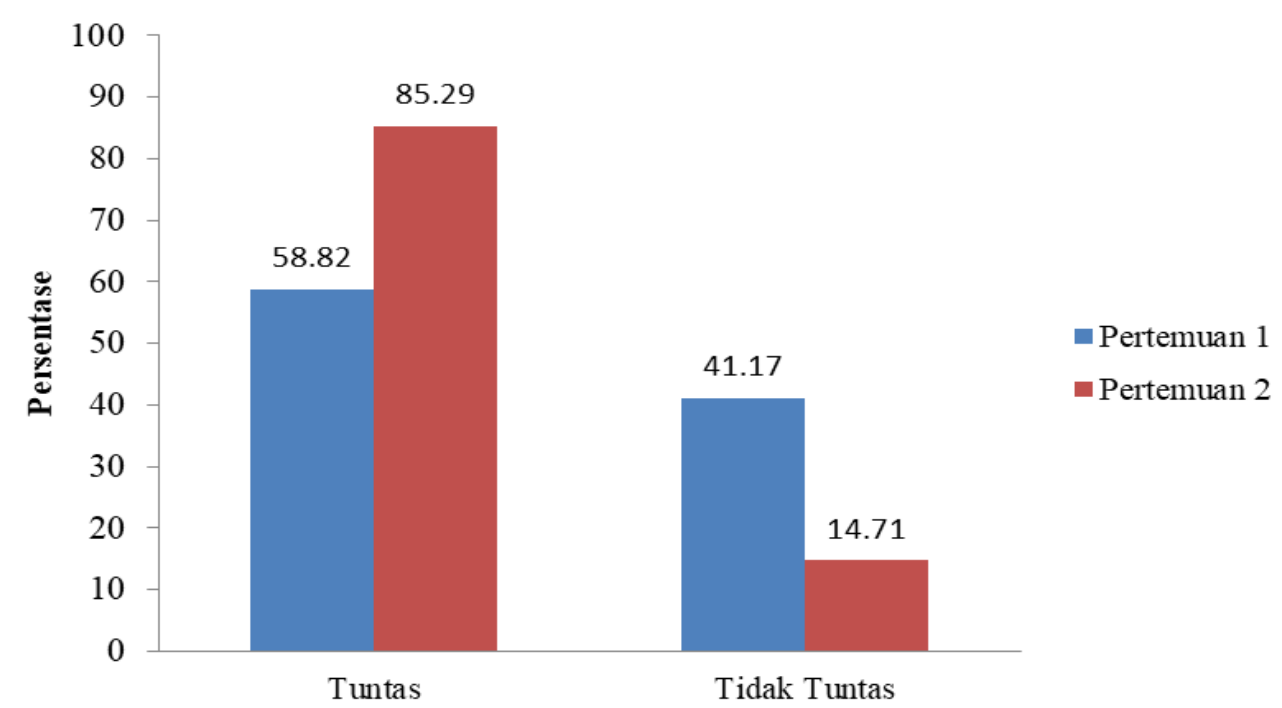

Gambar 1. Grafik Penigkatan Hasil Belajar pada Siklus 1

\subsubsection{Siklus 2}

Pada siklus II, petemuan pertama pembelajaran adalah mengerjakan praktek spreadsheet di komputer belum dapat dikerjakan dengan teratur mengerjakannya dengan model betukar pasangan dalam tiga kelompok, satu kelompok terdiri dari 2 orang dalam arti satu komputer ditempati oleh dua orang. Jadi mereka bertukar pasangangan untuk tiga komputer mengerjakan satu siklus akuntansi secara bergantian dengan tanggung jawab masing-masing tugas belum dapat mengerjakan tugasnya dengan sempurna. Untuk itu pada pertemuan kedua siklus 1( pertama) akan diperbaiki lagi agar lebih efektif belajar dengan model pembelajaran yang dilakukan. Berdasarkan hasil pengumpulan data pada Siklus II, pertemuan pertama dan pertemuan kedua maka diperoleh rekapitulasi sebagai berikut.

Tabel 4. Rekapitulasi Data Pengamatan Proses Belajar pada Siklus 2 Pertemuan Ketiga

\begin{tabular}{llcccc}
\hline & & & & \multicolumn{3}{c}{ SCORE } \\
\cline { 4 - 6 } NO & AKTIVITAS & siswa & $\mathrm{A}$ & $\mathrm{B}$ & $\mathrm{C}$ \\
$\mathbf{1}$ & Kesiapan belajar & 34 & 1 & 12 & 21 \\
$\mathbf{2}$ & Interaksi antarsiswa & 34 & 0 & 10 & 24 \\
$\mathbf{3}$ & Interaksi siswa guru & 34 & 3 & 6 & 25 \\
$\mathbf{4}$ & Mengumpulkan tugas tepat waktu & 34 & 0 & 8 & 26 \\
$\mathbf{5}$ & Mengerjakan tugas sesuai petunjuk & 34 & 0 & 11 & 23 \\
$\mathbf{6}$ & Tidak menyontek & 34 & 3 & 27 & 4 \\
& Jumlah & 204 & 7 & 74 & 123 \\
& Presentasi & $100 \%$ & $3.43 \%$ & $36.27 \%$ & $60.29 \%$ \\
\hline
\end{tabular}

Tabel 5. Rekapitulasi Data Pengamatan Proses Belajar pada Siklus 2 Pertemuan Keempat

NO

AKTIVITAS

1 Kesiapan belajar

2 Interaksi antarsiswa

3 Interaksi siswa guru

4 Mengumpulkan tugas Tepat waktu

SCORE

\section{$\sum$ siswa}

34

34

34

34

\begin{tabular}{ccc}
\hline A & B & C \\
19 & 10 & 5 \\
9 & 20 & 5 \\
19 & 9 & 6 \\
19 & 8 & 7 \\
\hline
\end{tabular}




\begin{tabular}{cccccc}
\hline $\mathbf{5}$ & Mengerjakan tugas sesuai petunjuk & 34 & 10 & 18 & 6 \\
$\mathbf{6}$ & Tidak menyontek & 34 & 20 & 12 & 2 \\
& Jumlah & 204 & 96 & 77 & 31 \\
& Presentasi & $100 \%$ & $47,06 \%$ & $37,74 \%$ & $15,20 \%$ \\
\hline
\end{tabular}

Dari Observasi dan hasil pengamatan yang dimasukkan dalam rekapitulasi tersebut diatas diperoleh hasil penilaian bahwa untuk pengamatan proses belajar kesiapan belajar, Interaksi antar siswa, interaksi siswa guru, mengumpulkan tugas tepat waktu, mengerjakan tugas sesuai petunjuk dan tidak menyontek scorenya sudah menunjukkan peningkatan. Demikian juga untuk penilaian dokumen hasil kerja kelompok dengan kreteria Ketelitian, kesesuaian dengan tugas, kebenaran jawaban dan tanggung jawab scorenya juga sudah menunjukkan peningkatan. Dari hasil sumatif observasi pekerjaan masing-masing siswa dapat dilihat dengan penilaian meningkat rata-rata memperoleh nilai 80 keatas, 28 orang yaitu $76 \%$, memperoleh nilai 75-79, 4 orang $14.71 \%$, memperoleh nilai dibawah KKM 2 orang yaitu 2.94 $\%$.

\subsubsection{Siklus III}

Pada siklus II, petemuan pertama pembelajaran adalah mengerjakan praktek spreadsheet di komputer belum dapat dikerjakan dengan teratur mengerjakannya dengan model betukar pasangan dalam tiga kelompok, satu kelompok terdiri dari 2 orang dalam arti satu komputer ditempati oleh dua orang. Jadi mereka bertukar pasangangan untuk tiga komputer mengerjakan satu siklus akuntansi secara bergantian dengan tanggung jawab masing-masing tugas belum dapat mengerjakan tugasnya dengan sempurna. Untuk itu pada pertemuan kedua siklus III( pertama) akan diperbaiki lagi agar lebih efektif belajar dengan model pembelajaran yang dilakukan. Berdasarkan hasil pengumpulan data pada Siklus III, pertemuan kelima dan pertemuan keenam maka diperoleh rekapitulasi sebagai berikut.

Tabel 6. Rekapitulasi Data Pengamatan Proses Belajar pada Siklus 3 Pertemuan Kelima

\begin{tabular}{|c|c|c|c|c|c|}
\hline \multirow{2}{*}{ NO } & \multirow{2}{*}{ AKTIVITAS } & \multirow{2}{*}{$\sum$ siswa } & \multicolumn{3}{|c|}{ SCORE } \\
\hline & & & $\overline{\mathrm{A}}$ & B & $\bar{C}$ \\
\hline 1 & Kesiapan belajar & 34 & 26 & 7 & 1 \\
\hline 2 & Interaksi antarsiswa & 34 & 28 & 4 & 2 \\
\hline 3 & Interaksi siswa guru & 34 & 19 & 9 & 6 \\
\hline 4 & Mengumpulkan Tugas Tepat waktu & 34 & 30 & 4 & 0 \\
\hline 5 & Mengerjakan tugas sesuai petunjuk & 34 & 27 & 6 & 1 \\
\hline 6 & Tidak menyontek & 34 & 29 & 5 & 0 \\
\hline & Jumlah & 204 & 159 & 35 & 10 \\
\hline & Presentasi & $100 \%$ & $77.94 \%$ & $17.16 \%$ & $4.90 \%$ \\
\hline
\end{tabular}

Untuk hasil belajar peserta didik pada siklus III mengalami peningkatan dibandingkan hasil belajar pada siklus II dan Siklus I. Untuk penilaian dokumen hasil kerja kelompok dengan kreteria Ketelitian, Kesesuaian dengan tugas, Kebenaran jawaban dan Tanggung jawab scorenya juga sudah menunjukkan peningkatan sesuai dengan yang diharapkan diperoleh hasil subsumatif observasi pekerjaan masing-masing siswa dapat dilihat dengan penilaian meningkat rata-rata memperoleh nilai 80 keatas. Adapun grafik peningkatan hasil belajar peserta didik dapat ditampilkan dalam gambar berikut. 


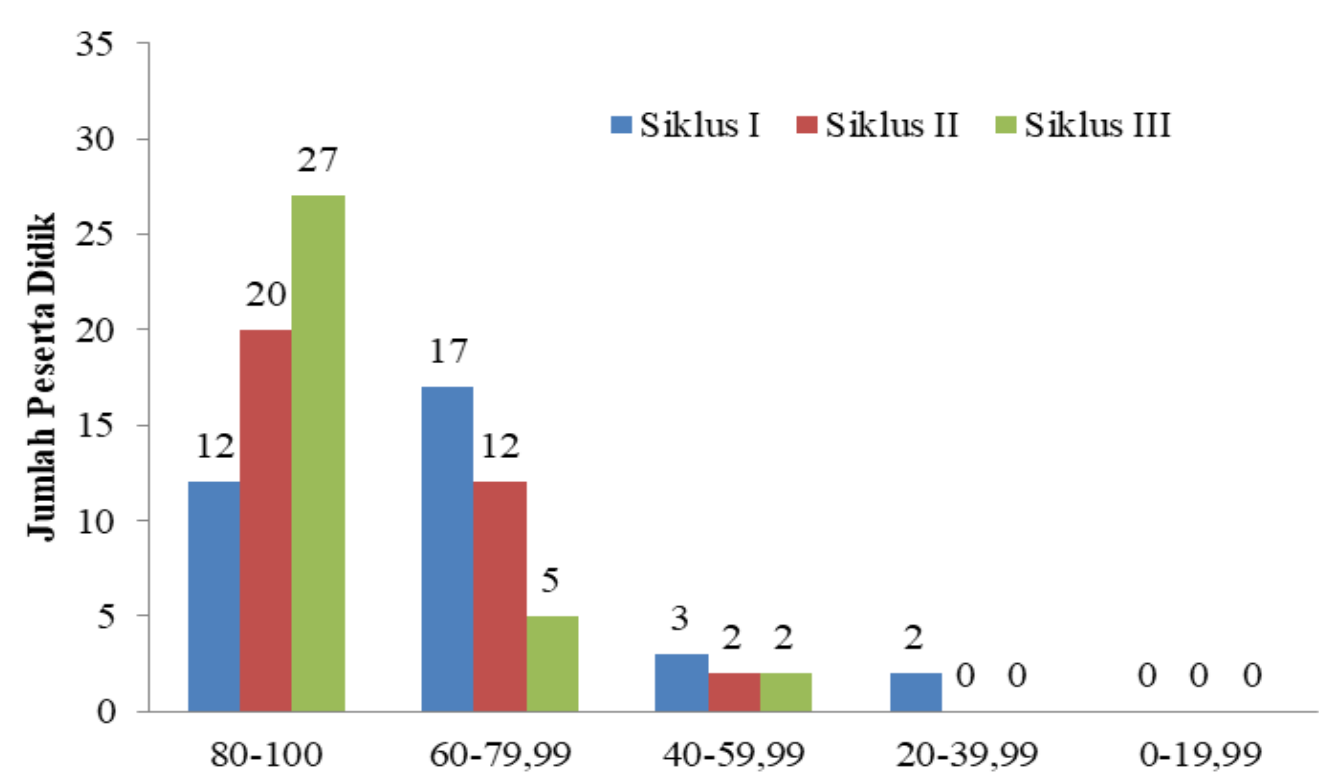

Gambar 2. Peningkatan Hasil Belajar pada Model Bertukar Pasangan

\subsection{Pembahasan}

Tindakan Siklus III ternyata mampu mengubah sikap belajar siswa terutama pada saat mengikuti kegiatan belajar mengajar dan mampu meningkatkan motivasi siswa untuk belajar sehingga hasil belajar siswa meningkat serta dapat terlihat bahwa daya serap siswa terhadap mata diklat aplikasi pengolahan angka ( spreadsheet)di Komputer semakin meningkat. Kegiatan belajar yang menggunakan alat praktek (Komputer) sangat menarik bagi siswa. Pembelajaran dengan Bertukar Pasangan merupakan model yang sangat baik untuk meningkatkan keaktifan belajar siswa [11][12]. Hal ini karena pembelajaran dengan model ini mencakup tiga ranah pengetahuan yaitu (1) Afektif, (2) Kognitif dan (3) Psikomotor. Materi-materi yang disajikan dengan model ini mudah diingat dan dipahami siswa. pembelajaran kooperatif memiliki peran dan manfaat yang besar bagi siswa. Dengan menerapkan model pembelajaran kooperatif ini siswa akan terlibat aktif dalam kelompok untuk bersama-sama memecahkan soal yang diberikan guru [13][14].

Secara umum hasil tindakan pada siklus 3 dari hasil aktifitas, hasil observasi kerja kelompok oleh observer, dan hasil tes formatif, sumatif dapat dikatakan bahwa metode pembelajaran Bertukar Pasangan dapat meningkatkan daya serap siswa terhadap mata diklat Aplikasi pengolahan angka pada komputer mengerjakan Siklus Akuntansi yang ditandai dengan meningkatnya prestasi dan hasil belajar siswa.

\section{Kesimpulan}

Dari hasil pembahasan diatas disimpulkan data peningkatan kegiatan kreativitas peserta didik diantaranya terjadi perubahan dalam aspek keaktifan belajar siswa. pembelajaran dengan model ini mencakup tiga ranah pengetahuan yaitu (1)Afektif, (2) Kognitif dan (3) Psikomotor. Peningkatan Daya serap siswa terhadap mata diklat Aplikasi Pengolahan Angka di komputer dapat dilakukan dengan menggunakan pembelajaran Bertukar Pasangan. Akan lebih baik lagi bila satu computer satu orang. Pembelajaran Bertukar pasangan ternyata mampu meningkatkan perhatian siswa terhadap pokok bahasan yang diajarkan. Siswa terarahkan perhatiannya pada materi yang diajarkan dan mampu meningkatkan hasil belajar. Pembelajaran Bertukar pasangan dapat mengoptimalkan pemakaian sarana dan prasarana yang ada disekolah terutama pemakaian ruang praktek Komputer 


\section{Daftar Pustaka}

[1] Dyah Widowati, "PENYELARASAN KURIKULUM PENDIDIKAN VOKASI (STUDY KASUS SMKN 10, SMK ADHIKAWACANA SURABAYA, DAN POLITEKNIK NSC SURABAYA,” J. Bisnis Teknol. Politek. NSC Surabaya, 2015.

[2] P. B. Herlandy, D. E. Ratna, and E. Ismanto, "Pengembangan Media Pembelajaran Dengan Adobe Flash Pokok Bahasan Komunikasi Dalam Jaringan Untuk Kelas X SMK," CIRCUIT J. Ilm. Pendidik. Tek. Elektro, vol. 3, no. 1, pp. 29-40, 2019.

[3] R. Culatta, “Conditions of Learning ( Robert Gagne )," Instructional Design. 1992.

[4] K. Celuch, B. Bourdeau, and D. Winkel, "Entrepreneurial identity: The missing link for entrepreneurship education," J. Entrep. Educ., 2017.

[5] M. dan Dimyati, "Model-model pengajaran dan pembelajaran," Teach. Educ., 2013.

[6] H. Maksum, "Model Project Citizen Untuk Meningkatkan Kecakapan Pendidikan Kewarganegaraan Dalam Mengembangkan Sikap Nasionalisme," J. Pendidik. Serambi Ilmu (Wadah Inf. Ilm. dan Kreat. Intelekt. Pendidikan), 2011.

[7] A. Senen, "Mengembangkan pembelajaran IPS dalam perspektif paradigma konstruktivistik," J. Pendidik. Dasar Din., 2014.

[8] E. Suherman, "Model Belajar Dan Pembelajaran Berorientasi Kompetensi Siswa," J. Pendidik. Dan Budaya, 2008.

[9] A. Jaelani, "PEMBELAJARAN KOOPERATIF, SEBAGAI SALAH SATU MODEL PEMBELAJARAN DI MADRASAH IBTIDAIYYA (MI)," Al Ibtida J. Pendidik. Guru MI, 2015.

[10] S. Arikunto, "Prosedur Penelitian Tindakan Kelas," Bumi Aksara, 2006.

[11] Kasnati, "MODEL PEMBELAJARAN BERTUKAR PASANGAN," Suara Guru J. Ilmu Pendidik. Sos. sains, dan Hum., vol. 2, no. 2, 2016.

[12] S. Wulandari, S. Buwono, and R. Rosyid, "EFEKTIVITAS MODEL BERTUKAR PASANGAN PADA PERSAMAAN DASAR AKUNTANSI TERHADAP HASIL BELAJAR SISWA DI SMA," J. Pendidik. dan Pembelajaran, 2013.

[13] I. R. Hidayah, "PERBEDAAN MODEL BERTUKAR PASANGAN DENGAN MAKE A MATCH TERHADAP HASIL BELAJAR PECAHAN," J. Pendidik. Guru Sekol. Dasar, vol. 33, no. 7, pp. 283-290, 2018.

[14] S. Muryaningsih and A. Mustadi, "Pengembangan Rpp Tematik-Integratif Untuk Meningkatkan Karakter Kerja Keras Di Sekolah Dasar,” J. Prima Edukasia, 2015. 